\title{
Competition between great powers and a looming strategic arms race in the Asia-Pacific
}

\author{
Xi Luo ${ }^{1,2}$
}

Received: 20 May 2021 / Accepted: 16 June 2021 / Published online: 29 June 2021

(c) The Institute of International and Strategic Studies (IISS), Peking University 2021

\begin{abstract}
As competition between the United States and Russia intensifies, the importance of nuclear weapons is rising and innovation with regard to associated technologies is gaining momentum in both countries. The other regional nuclear-armed states, such as India, Pakistan, and the Democratic People's Republic of Korea (North Korea), also have impetus to implement their own nuclear modernization plans. The AsiaPacific region seems to be on the brink of a strategic arms race amidst bleak international arms control and related progress. As a permanent member of the UN Security Council and a nuclear-weapon state, China has played constructive roles in the international arms control process and should take on more responsibilities in this tough era.
\end{abstract}

Keywords Strategic competition · Arms race · Arms control · The Asia-Pacific region

\section{Introduction}

As China gains influence as a great power with the world's largest (as measured by purchasing power parity) or second-largest (as measured by nominal GDP) economy, the strategic studies' community has concluded that strategic competition between great powers is now intrinsically trilateral rather than bilateral, as it was during the Cold War. With China involved, great power competition has become more complex and multi-dimensional. In technological, economic, and ideological realms, Beijing is viewed as a peer competitor and even a challenger by Washington. These trends prompted former United States President

Xi Luo

luoxi524@126.com

$1 \quad$ PLA Academy of Military Science, Beijing, China

2 Visiting Research Fellow of Center for Arms Control and Nonproliferation Studies, Institute of American Studies, Chinese Academy of Social Sciences, AMS, Haidian District, Beijing, China 
Donald Trump to shift from the traditional post-Nixonian U.S. "engagement" policy to one of "decoupling" and "containment." Since current President Joseph Biden came to office, America's policy on China policy has undergone a round of adjustment, but Washington still views China as a more assertive competitor (Biden 2021).

In the nuclear arena, China is now one of the triadic nuclear powers that possess land-based, airborne, and at-sea strategic nuclear weapons, and has been asked to participate in what were hitherto bilateral arms control negotiations, even though China holds an order of magnitude fewer nuclear weapons than the United States and Russia (Zala 2019). The United States and Russia have accelerated modernization of their own nuclear arsenals and increased the role played by nuclear weapons in their national security policies. Many observers predict that a new nuclear arms race is unavoidable and that the strategic stability between two major nuclear powers that existed after the Cold War is now obsolete (Gorbachev 2018).

Deepening strategic rivalry, unilateral non-compliance with and withdrawals from strategic arms treaties, as well as nuclear modernization activities and the introduction of entirely new weapons systems have undermined and controverted the existing international arms control process. Several milestone arms' control treaties and agreements have been abandoned or face an uncertain future, even under the Biden Administration. These new factors-more players, linked in complex ways, modernization activity, plus new technologies, and the bleak outlook for arms control-make a new nuclear arms race not only probable, but also likely to be more dangerous and costly than before. Therefore, it is urgent that all states in the region, but especially the nuclear-armed great powers, cooperate to lessen the risk of an accidental nuclear conflict or a costly nuclear arms race.

To this end, this paper asks the following questions:

1. Driven by the renewal of major power rivalry, what are the potential military flashpoints and nuclear dangers in the Asia-Pacific region?

2. How does great power rivalry affect the prospect for cooperative efforts to reduce nuclear dangers?

3. Is it possible and reasonable to insist that China join in the trilateral arms control negotiation that the United States has tried to convene?

4. What kind of roles has China played in the international nuclear order, and how might it contribute to international arms control and the non-proliferation process in the future?

5. Is it possible, and if so, how might states reduce the risk of a dangerous strategic arms race in this region?

In summary, this essay contemplates, from a Chinese perspective, the worsening strategic rivalry between the great powers, surveys the present and prospective threat environment relative to the spread of nuclear weapons in Asia, reviews emerging strategic weapon systems and technologies, analyzes the relevant risks resulting from these trends and the adequacy of existing institutions to address 
proliferation challenges, and then explores ways of curbing and even reversing such trends. The overarching goal is to contribute to the rejuvenation of the nuclear arms control process and the avoidance of conflicts based on misinformation and mistaken assumptions about adversarial intentions.

\section{Power shift and a worsening strategic rivalry}

Since the end of the Cold War, the Asia-Pacific region has undergone two power shifts. The first was from the Cold War equilibrium of the two major superpowers to U.S. dominance. The second was from the short-lived absolute U.S. dominance to a three-power system that includes China. Characterized by China's economic and military rise and the reemergence of an assertive Russia, the triangular strategic relationship will have an enormous effect on global peace and regional security. The first worrisome manifestation of the new tri-polarity was the deterioration of Russia-U.S. relations in the wake of the Ukraine crisis. The continued deterioration of U.S.-Russian relations has degraded the security of the Asian-Pacific region.

The other outstanding trend is the deterioration of the Sino-U.S. relationship, which is rooted in the power shift and addressed in realist transition theory (Shambaugh 2005; Fravel 2007). According to one exponent, political scientist and Harvard professor Graham Allison, transitioning from an order dominated by one great power that is then challenged by another substantial power, is fraught with peril and destined to cause increased risk of clashes and even war (Allison 2017).

It was more than 10 years ago that the U.S.-China relationship became the most important bilateral relationship in the world. Under the Obama administration, the United States began to adjust its China policy, but it still emphasized cooperation and engagement. After President Trump took office in 2017, the United States accelerated the pace of its China policy adjustment and deepened its suspicion toward China's rise. A new "Washington consensus" emerged that the traditional China policy had failed and that the United States must toughen its China stance. In its 2018 National Defense Strategy (NDS) and Nuclear Posture Review (NPR), as well as relevant strategic documents released by the Trump administration, China was listed as the first threat to U.S. national security, ahead of Russia, North Korea, Iran, and the Islamic State (U.S. Department of Defense 2018). These documents suggested that U.S. security focus would pivot from counterterrorism after the September 11, 2001 attack, to great power competition because of China's rise (Garamone 2018).

Driven by great power competition and corresponding mistrust and misunderstanding, the deterioration of the Sino-U.S. relationship has manifested in many issues, such as economic and trade frictions, disputes over intellectual property rights, technological decoupling, the Hong Kong issue, the Taiwan issue, and disputes in the South China Sea. Economically, the Trump administration initiated several trade conflicts and stepped up accusations against China of unfair trade practices. On the Taiwan issue, Trump provoked controversy when he floated the idea of increasing official contacts with Taiwan early in his term and then released several presidential orders relevant to relations with Taiwan. In the South China Sea, the United States strengthened its freedom of navigation operations and increased 
military ties with its regional allies. In the high-technology area, due to fears about Chinese companies playing a role in upgrading American infrastructure, Washington imposed sanctions on Chinese high-tech enterprises. These disputes intensified tensions that had already emerged during the Obama administration, which had moved to strengthen U.S. alliances in Asia and to shift more military assets to the Asia-Pacific region as part of its "rebalance to Asia" strategy. China has, in turn, dismissed U.S. concerns about the construction of artificial islands in the South China Sea, redoubled its criticism of U.S. security leadership in Asia, and tightened its claims on disputed maritime territories.

The shift from cooperative engagement to competition was fast and unexpected, and its effects have been magnified by the COVID-19 pandemic. Since early 2020, China-U.S. relations have deteriorated at an even faster pace. Official relations between the two countries are almost frozen, and the mutual antipathy among the two peoples is unprecedented. China-U.S. relations have experienced the most serious degradation since the normalization of diplomatic ties in the early 1970s. What will happen next is hard to predict.

\section{A looming strategic arms race of the region}

In the Asia-Pacific region, the post-Cold War international order has evolved from bipolar global competition to a rising strategic rivalry among the three great powers. The return of great power rivalry made the United States and Russia realize that they should enhance their own strategic deterrence capabilities. The dramatic deterioration of the global and regional threat environment gave other regional nucleararmed states (such as India, Pakistan, and the DPRK) impetus to implement their own nuclear modernization plans. The rising number of regional actors with nuclear arsenals or nuclear aspirations may cause more nuclear threats and localized nuclear arms races while adding complexity to the tripolar nuclear standoff. Meanwhile, many more nuclear and non-nuclear states aspire to acquire missiles and missile technologies that lead to vertical and horizontal missile proliferation and enable the projection of a nuclear threat.

The United States and Russia, which account for more than $90 \%$ of the world's nuclear weapons, have accelerated the modernization of their nuclear arsenals. According to a report released by the U.S. Congressional Budget Office (CBO) in January 2019, it will cost an estimated \$494 billion to modernize and operate the U.S. nuclear arsenal and facilities that support it during the period from 2019 to 2028 (Congressional Budget Office 2019). After a 1-year review process, the Trump administration published the 2018 Nuclear Posture Review (NPR) report which reversed Obama's attempt to downplay nuclear weapons and instead recommended increasing the role of U.S. nuclear weapons (U.S. Department of Defense 2018). The report rejected limiting the role of nuclear weapons to the sole purpose of deterring nuclear attacks, and instead emphasized "expanding" U.S. nuclear options to deter, and, if deterrence fails, to prevail against both nuclear and "non-nuclear strategic attacks." To be clear, any use of a nuclear weapon to respond to a non-nuclear strategic attack would constitute nuclear first use (Kristensen and Korda 2020a). 
To "hedge against the potential nuclear and non-nuclear strategic threats," the NPR emphasized that the United States should "expand flexible U.S. nuclear options." Instead of Obama's promised "no researching and deploying new kinds of nuclear warheads," the new NPR reintroduced two low-yield warhead types in response to the deteriorating relations with Russia and China (U.S. Department of Defense 2018). The United States already deployed a low-yield warhead (W76-2) for the submarine-launched ballistic missile in late 2019. The W76-2 is a new single-stage warhead with a low yield (an estimated 5-7 kilotons), which modified an existing W76-1 two-stage thermonuclear warhead with the yield of 90 kiloton (Kristensen and Korda 2020a). It also began to redevelop a nuclear sea-launched cruise missile, or SLCM-N, as another vital component of its comprehensive nuclear modernization plan (Mercado 2020). This nuclear submarinelaunched cruise missile aims to provide a nonstrategic regional presence, largely to offset China's land-based intermediate-range missiles not controlled under the bilateral Intermediate Nuclear Forces treaty, now abandoned by the United States. Additionally, the United States tested a ground-based cruise missile in August and a ground-launched, intermediate-range ballistic missiles in December 2019; these were conventionally-armed (Mehta 2019), but could be modified to use nuclear warheads. All these capabilities are deemed necessary by the United States to enhance U.S. regional deterrence capabilities and counter a limited nuclear attack.

For its part, Russia has re-emphasized nuclear weapons as integral to reclaiming a major power role after the collapse of the former Soviet Union. It began an ongoing nuclear modernization program in the late 1990s. According to President Vladimir Putin's report in late 2019, modernized equipment now accounts for 82 percent of Russia's nuclear triad (Russian Federation Defence Ministry 2018). Russia's declaratory policy is developing and deploying nuclear weapons to deter, and if necessary, prevail in a regional war-a strategy known as "escalate to de-escalate."

Russia's strategic modernization program has three elements. First, it is routinely replacing aging warheads and delivery systems. Russia's nuclear triad consists of land-based international ballistic missiles (ICBMs), submarine-launched ballistic missiles (SLBMs), and strategic bombers. The land-based component of the strategic triad includes two versions of the SS-27: Mods 1 and 2. The focus of the current and bigger phase of Russia's modernization is the SS-27 Mod 2 ICBM (known in Russia as RS-24 Yars) which are equipped with four multiple, independently targetable reentry vehicles (MIRVs). Russia is also developing the heavy multiple-warhead ICBM (SS-X-29) known as Sarmat, and is ready to finish serial production in 2021 to replace the SS-18 (Army Technology 2010). In the sea-based component, Russia has already announced a plan to build five and purchase two more new Borei class submarines (Project 955A) to replace the older Delta IV SSBNs (Project 667BDRM) after 2023 (Kristensen and Korda 2020b). Russia has also resumed production of the Tu-160 aircraft in 2019 and is expected to field the first ten Tu$160 \mathrm{M} 2 \mathrm{~s}$ before 2027.

Second, Russia has begun to modernize tactical nuclear weapons. As of early 2020, Russia has a stockpile of roughly 4310 nuclear warheads assigned for use by long-range strategic launchers and shorter range tactical nuclear forces. Of these, 
roughly 1570 strategic warheads are deployed, and another 870 strategic warheads are in storage, along with about 1870 nonstrategic warheads.

Third, Russia has begun to develop, test, and produce new "exotic" types of nuclear weapons. In March 2018, President Putin listed these planned and new nuclear weapons capabilities:

- a nuclear-armed, maneuvering hypersonic glide vehicle (the Avangard) carried by a modified SS-19 and later SS-29;

- a nuclear-powered, nuclear-armed cruise missile of "unlimited" range (the Burevestnik) to penetrate adversary's missile defense systems;

- an air-launched ballistic missile purportedly to target ships (the Kinzhal);

- a nuclear-powered anti-ship hypersonic cruise missile (the Tsirkon);

- an SS-18 follow-on ICBM with modern features to penetrate missile defenses (the Sarmat);

- a deep-diving, unmanned, nuclear-powered, and nuclear-armed underwater delivery vehicle (the Poseidon) that is scheduled for delivery in 2027 (President of Russia 2018).

All of these programs illustrate that Russia is determined to continue its reliance on nuclear weapons as a key element of its national security strategy. Especially, the new "exotic" nuclear weapons provide means to augment existing nuclear forces with systems that are not counted under the New Strategic Arms Control Treaty (New START), now extended by the United States and Russia for 5 years, since President Biden was elected.

The dynamics described above in the U.S. and Russian nuclear arms replacement and modernization doctrine and deployment converge to suggest that this nuclear arms race between the United States and Russia will be different from that during the Cold War. In the late 1960s and early 1970s, the number of deliverable weapons in the Soviet and U.S. nuclear arsenals was approximately equal. Their key strategic nuclear objectives were to obtain sufficient capacity to inflict a certain level of assured damage to the other one in a retaliatory strike. Driven by the reality of assured retaliation and near certainty of mutual annihilation in a nuclear war, the two nuclear superpowers had little incentive to attempt to preemptively strike the other's strategic nuclear forces. During the second half of the Cold War, Soviet leaders became uncertain that they could indefinitely maintain a prospect of guaranteed retaliation and mutual annihilation (Green and Long 2017). Two decades after the Cold War ended, we find that the principles guiding the numbers or size of nuclear weapons have changed. On one hand, the United States re-emphasized nuclear deterrence, boosted its nuclear modernization, and acted skeptically toward arms control measures. Thus, the guiding principles that shape the size and type of U.S. nuclear forces have shifted from preserving strategic stability between the nuclear great powers to countering strategic threats from nuclear adversaries, whether they be small, medium, or great powers. Conversely, Russia's nuclear modernization is still motivated in part by Moscow's strong desire to maintain overall numerical parity with the United States. The Russian leadership perceives that the U.S. ballisticmissile defense system constitutes a real future risk to the credibility of Russia's 
retaliatory capability. In an action-reaction dynamic, Russia began to research and develop new nuclear systems to counter deployment of U.S. missile defenses. This unrestrained nuclear competition between the United States and Russia may complicate future bilateral arms control negotiation and potentially affect China's understanding of its own nuclear retaliatory capabilities (Glaser and Fetter 2016).

Apart from the major powers, more and more regional states have acquired the scientific, technological, and industrial capabilities to produce ballistic missiles or cruise missiles, which undermine the efforts of restraining the proliferation of both missiles (Nuclear Threat Initiative 2015). The DPRK, India, and Pakistan have declared their possession of nuclear weapons and demonstrated their ability to use ballistic missiles. The DPRK test-fired an inter-continental range ballistic missile, which can reach at least the west coast of America, some $8000 \mathrm{~km}$ away. India flight-tested a system with a range of 3500-5000 km. Pakistan also has intermediate-range ballistic missiles able to carry nuclear warheads over $2750 \mathrm{~km}$. Evidently, states will continue developing or acquiring missiles and the related technologies despite interdiction, international condemnation, sanctions, and asymmetric efforts to limit them.

\section{The "Post-INF" capabilities and major powers" strategic interactions}

Despite the fact that the Intermediate-Range Nuclear Forces Treaty (INF) ended in 2019, the issue of INF-range missiles has not disappeared. For America, its withdrawal was driven by Russia's alleged treaty violations and China's rising conventional and also nuclear-armed missile capabilities. Under the former Trump Administration, the United States held that if it remained bound by the INF treaty limits, then the United States would be increasingly at a disadvantage with respect to Russia and China. American analysts argued that China has deployed thousands of landbased intermediate-range ballistic and cruise missiles, and 95 percent of them would violate the INF if China was party to it, which, of course, it is not (Stokes 2019, 2). After the U.S. withdrew the INF, Russia decided to suspend its obligations with respect to the INF treaty as a countermeasure. The Biden Administration is watching Russia's and China's potential employment of nuclear and conventional armed intermediate-range ballistic and cruise missiles, with intent to seek negotiations on a global treaty to ban them (Squassoni 2021). The termination of the treaty means that the Asia-Pacific region has entered into a "post-INF" era in which, as is explained below, "post-ballistic" capabilities become a priority in military planning for these states and tripolar great power strategic interactions become more complex.

The "post-ballistic" capabilities arise from emerging technologies, such as advanced guidance and stealth technology. Enhanced by these new technologies, a new generation of cruise missiles and tactical (shorter-range) ballistic missiles gained greater accuracy, reliability, and affordability than the long-range ballistic missiles. Modern cruise missiles can fly at low altitudes below radar coverage, which make them less visible to radars and more difficult to detect and defend against, as well. Shorter range ballistic missiles, with their accuracy measured in 
meters, have become effective tools for taking out high-value, well-defended targets inside an adversary's territory.

However, these attributes leave target nations a very limited ability to counter the new generation of missiles in wartime. Hypersonic vehicles with speeds of Mach 5 and above, for example, can drastically reduce the timelines for attack and response. The further proliferation of hypersonic missiles and the related technologies may cause miscalculation and misperception. Hypersonic weapon systems are divided into hypersonic glide vehicles and hypersonic cruise missiles. The United States, Russia, France, Japan, China, and India are all pursuing, and Russia has deployed, earlier versions of these weapons. Furthermore, the growing popularity of dualcapable missiles, when equipped with either conventional or non-conventional warheads, is also destabilizing and could lead to devastating deterrence failures, because this payload ambiguity increases uncertainty in a crisis, and thereby the stakes in not striking first.

Russia has tested and fielded a new ground-launched cruise missile system (9M729), which the United States declared violated the INF treaty since May 2013 (U.S. Congressional Research Service 2019). Over the last 2 decades, China has deployed several new models of land-attack and anti-ship conventional cruise missiles which are viewed by the United States as providing what it calls "Anti-access/ Area-denial" (A2/AD) capability. On August 3, 2019, the day after the United States withdrew from the INF Treaty, then-U.S. Secretary of Defense Mark Esper revealed that the United States aims to deploy INF-range missiles in the Asia-Pacific to counter China's "A2/AD” capabilities (Kobza 2019, 11). At the same time, the Pentagon initiated a study to evaluate whether the United States needed new military capabilities to offset any advantage Russia and China might acquire by deploying a groundlaunched cruise missile of INF range (between 500 and $5500 \mathrm{~km}$ ). The potential U.S. Army and/or Marine Corps options to deploy land-based intermediate-range missiles in this region include: the intermediate-range ballistic missile (IRBM) with hypersonic glide vehicle, with range of $4000 \mathrm{~km}$; the Tomahawk ground-launched cruise missile (GLCM), with the range of less than $2500 \mathrm{~km}$; The Improved Army Tactical Missile System (ATACMS), with the range of less than $700 \mathrm{~km}$; and the Precision Strike Missile (PrSM), with the range of $499 \mathrm{~km}$ (Ogilvie 2020, 3).

The potential deployment of the previously prohibited ground-based INF-range missiles by the United States in the Asia-Pacific region, especially in the western Pacific, may increase the complexity of trilateral great power strategic interactions. In response, some Chinese scholars have suggested that China should increase the survivability of its nuclear forces by deploying multiple warheads on missiles, and experimenting with hypersonic boost-glide vehicles, etc. (Zhao 2019). Some analysis outside China even speculated that Beijing might change its longstanding nofirst-use (NFU) commitment and the minimum nuclear deterrence posture (Baklitskiy 2019). Yet, to date, in spite of the speculation of some in Washington that it would amend its NFU policy in the near future, China has upheld its NFU commitment to non-nuclear states.

As for Russia, President Putin announced that Russia will deploy new missile systems and augment its missile defense in its eastern regions (Blank 2019). Russia also took other countermeasures that enhance Sino-Russian military ties and 
help China to boost its own missile defensive systems (The Guardian 2019). The Sino-Russian military cooperation between their respective missile defense systems can be traced back to U.S. withdrawal of the Anti-Ballistic Missile Treaty (ABM) in 2002. Driven by the U.S. potential development of the aforementioned missiles, Sino-Russian relations gained new momentum recently; this was deemed a "comprehensive strategic partnership" by China and "an allied relationship" by Russia.

\section{Will China join the trilateral arms control negotiation?}

In early 2019, the Trump Administration began to push for a trilateral arms control that would include America, Russia, and China. Then-president Trump noted that "Russia, China and we are all making hundreds of billions of dollars' worth of weapons which are costly and ridiculous" (Sonne and Hudson 2019). In April 2020, the U.S. State Department released a report titled "U.S. Priorities for NextGeneration Arms Control," which outlined U.S. priorities for "next-generation arms control" involving both Moscow and Beijing (Ford 2020). The U.S. tended to cite China's participation as a pre-condition of the extension of the New START. The treaty limits U.S. and Russian deployed strategic nuclear forces, and additionally facilitates inspections and exchanges of information on the status and movements of their inter-continental ballistic missiles and heavy bombers.

At the time, U.S. proposals to trilateralize the existing U.S.-Russia arms control negotiation appeared disingenuous, given that relatively small Chinese nuclear forces are not equivalent to those of the United States and Russia (Kristensen and Korda 2020a). ${ }^{1}$ Leaving aside the quantitative and qualitative differences between the U.S.'s and China's nuclear forces, China's warheads and relevant delivery systems are stored at separated locations, which means that the existing New START counting rules are not suitable for China (Quinn 2019). Several Chinese spokesmen rejected Trump's calls officially, arguing that the two nuclear superpowers should [bear] the main responsibility of reducing their arsenals to lower levels (Ministry of Foreign Affairs of the PRC 2020). From Beijing's perspective, any request for trilateral arms control dialogue from the United States is more a litmus test of its campaign of maximum pressure toward China on a range of policy issues, and an excuse for its withdrawal from the treaty for non-substantive reasons. China also worried that verification of China's forces under a trilateral treaty could help to detect and weaken Beijing's limited nuclear retaliatory capabilities, which rely in part on opacity and ambiguity as a substitute for the limited nuclear force levels.

China's negative attitude toward trilateral strategic arms control negotiation does not mean that China does not support the international disarmament and non-proliferation process. As a permanent member of the UN Security Council and a nuclear-weapon state, China has played constructive roles in other multilateral nuclear-related negotiations. In the 1990s, China actively led negotiations on

\footnotetext{
1 According to Kristensen and Korda's assessment, Russia and the U.S. each maintain around 4000 operational nuclear weapons, while China has 350; see Kristensen and Korda (2021).
} 
military-to-military confidence building and risk reduction. It signed the multilateral 1996 Comprehensive Nuclear-Test-Ban Treaty and participated in the international monitoring systems being set-up to detect nuclear explosions around the world. China pushed for a treaty preventing an arms race in outer space (Gallagher 2019, 2). China also played a supportive role in negotiations leading to the 2015 multilateral Iran nuclear deal aimed at limiting that country's pathways to developing nuclear weapons. In the non-proliferation of missiles and their technologies, although it has not participated in any of the world's major export control mechanisms except for joining the Nuclear Suppliers Group in 2004, China joined the Hague International Code of Conduct against Ballistic Missile Proliferation (HCOC) and pledged to halt missile exports in 1992, 1994, 1998, and 2000. In August 2002, China promulgated its own missile export control regulations and lists that corresponded closely to the Missile Technology Control Regime (MTCR) guidelines (Einhorn and Samore 2002, 62). Since 2003, China has applied to join in the MTCR but failed when blocked by the United States.

When the United States shifted its China policy from engagement to containment under the Trump Administration - a posture likely to be maintained under the Biden Administration-China became even more sensitive to the United States' trilateral arms control initiative. Nonetheless, China embraces dialogue underpinned by the principles of fair, equitable, and concrete. China will participate in negotiations when involving in a broader set of negotiating partners, such as France and the United Kingdom, with similar levels of nuclear forces rather than being singled out. All five officially recognized nuclear-weapon states (the so-called "P5") convened and collaborated successfully in the Iran negotiations. From Beijing's perspective, a P5 format might be more conducive than the prospect of negotiating alone with the two nuclear superpowers. The P5 would be a good place for Beijing to negotiate confidence-building measures such as the No First Use (NFU) principle. Some Chinese scholars even support the notion that China could enter into nuclear arms control dialogues rather than nuclear arms reduction negotiations, because the concept of arms control is more comprehensive than arms reduction (Wu 2019).

\section{Reducing the risk of dangerous strategic arms races}

The rapidly worsening global security environment, exacerbated by the pandemic, has led to several missile-control treaties or agreements being abandoned or facing an uncertain future. The ABM Treaty and the Conventional Forces in Europe (CFE) Treaty collapsed. The termination of the INF Treaty highlights the fact that bilateral arms control ultimately would not curb the geographical spread and technological advancement of missiles. The Trump administration announced its withdrawal from the Open Sky Treaty. The 2010 New START, the only remaining treaty on limiting strategic ballistic missiles and strategic bombers, was saved only at the last moment by its extension by the Biden administration. Under Trump, even nuclear testing was put back on the agenda with unfounded American claims of the resumption of Chinese nuclear testing, which would have contravened the Comprehensive Nuclear Test Ban's "zero-yield" standard (U.S. State Department 2020)—reinforce just how 
far this negative trend went in the United States. Although many hope that the Biden administration will reverse this trend, structural trends at the global level involving the nine nuclear-armed states, and the chaotic state of American domestic politics and foundations of its foreign policy, mean that no one can predict its stance on these issues for longer than a few years.

China opposes an arms race outright due to its cost and potential strategic risks. From the Chinese perspective, the situation could be improved through the following measures. First, states should strengthen and enlarge existing missile-control institutions. A combination of deteriorating great-power relations, uncertainties about the impact of emerging technologies, and the fact some "post-INF" missiles are inherently attractive to states, with low political and legal barriers to acquisition and use, has undermined controls on missile proliferation. There is no universal norm, treaty, or agreement that governs the development, testing, production, acquisition, possession, transfer, deployment, or use of missiles. Apart from the bilateral missilecontrol treaties, the relevant mechanisms include unilateral (export controls), coordinated among exporting states as the Missile Technology Control Regime (MTCR), or multilateral but not legally binding and far-from-universal measures, such as the HCOC. Despite its imperfections, the MTCR - the only existing multilateral arrangement covering the transfer of missiles and missile-related equipment, material, and technology relevant to weapons of mass destruction (WMD) — has brought a significant degree of order to containing the spread of ballistic missiles. The Hague Code of Conduct (HCOC), an offspring of the MTCR and a useful set of voluntary confidence-building measures, refers only to one category of missiles.

The existing regulations covering missiles fall far short of those that would avoid a costly and potentially deadly arms competition. For those concerned and responsible states in this region, it is the right time to act now, or we will find ourselves beset by a destabilizing missile-related arms race. These existing instruments should give proper priority to cruise missiles and hypersonic missiles and even missile defense. The scope and number of participants should be enlarged. A regional missile-limitation regime that provides prior notice of missile and satellite launches to enhance transparency and predictability might also offer great strategic benefits to all states in the region (Akira 2004).

Second, all states-but especially the great power, nuclear-armed states-must do everything possible to avoid the risk of war and nuclear war. States that possess nuclear-armed missiles must ensure that no accident or incident ever happens. All the nuclear-armed states should take the famous saying "a nuclear war cannot be won and must never be fought" as a common understanding and restrain their development and employment of any ballistic or cruise nuclear missiles. Nuclear-armed states should be divided into three levels according to the quantities or qualities of their nuclear weapons. Each level should have different responsibilities.

The first level should be Russia and the United States which, as nuclear superpowers, have more than $90 \%$ of the world's nuclear warheads. The deterioration of great power relationships has increased the possibility of a nuclear arms race. Their negative attitudes toward arms control became a major barrier to the international non-proliferation progress. The nuclear superpowers should reduce the role of nuclear weapons in their military arsenals by rejecting preemptive nuclear 
strikes or declaring that the sole use of nuclear weapons is as "the last resort" to defend national security.

The second level should include France, Great Britain, and China, the other three members of the P5, or permanent UN Security Council member states. It is imperative to encourage these states to make more contributions in the international arms control process.

The third level would include the four de facto nuclear states: India; Pakistan; North Korea; and Israel, which are not members of the P5 and are outside the NPT. Their rights to exploit nuclear energy peacefully should be respected. Meanwhile, every effort should be given to limiting and reducing the risk of a nuclear war or conflict between India and Pakistan, to supporting the denuclearization process of the DPRK and rescuing the Iran nuclear deal, while guaranteeing national security, and to realizing eventually a Middle East WMD-free zone promoted by Israel.

Last but not the least, the new arms control and disarmament dialogue must address directly the new factors that could increase the risk of accidental or inadvertent nuclear conflict; most importantly, the potential destabilizing effects of new non-nuclear-weapon technologies, such as ballistic-missile defense, anti-satellite weapons, and precision-strike missile technology. These emerging advanced technologies supplement and even enhance nuclear weapons while offering nonnuclear states capabilities with which to offset the projection of conventional and nuclear forces by the great powers. With the widespread applications of emerging technologies, non-nuclear military facilities and platforms may degrade nuclear decision-making and increase the risk of an accidental nuclear war. Thus, Track 2 dialogues on emerging technologies and some non-nuclear-weapon systems might be useful for developing workable proposals to reduce the resulting risks.

The continued high-alert levels of American, Russian, British, and French warheads to support "launch on warning" is another risk that deserves urgent attention. Moreover, Russia, and the United States each possess huge counterforce capabilities, which threaten not only each other, but also lesser nuclear adversaries. In contrast, China, India, and Pakistan reportedly keep their nuclear weapons undeployed at central storage facilities, on low-alert levels. Their retaliatory strike capabilities are based on the principle of "launching under attack," not "launching under warning." China proposed that the P5 agree to adopt NFU as long ago as 1994, and this could lay the foundation for developing codes of conduct to decrease risks (Pan 2018). Recognizing the NFU principle could lessen the risk arising from misperception and misunderstanding of the preemptive strike posture on one hand, and sustain the taboo against nuclear employment on the other.

\section{Declarations}

Conflict of interest The author declares that there is no competing interest regarding the publication of this paper. 


\section{References}

Akira, Kurosaki. 2004. Moving beyond deterrence and missile defense. INESAP Briefing Paper. http://www.inesap.org/sites/default/files/Briefing13_04_0.pdf. Accessed 18 Apr 2020.

Allison, Graham. 2017. Destined for war: Can America and China escape Thucydides' trap? Boston: Houghton Mifflin Harcourt.

Army Technology. 2010. Russia to develop new heavy ICBM by 2020. https://www.army-technology. com/news/news105841-html/. Accessed 18 Apr 2020.

Baklitskiy, Andrey. 2019. What the end of the INF Treaty means for China. Carnegie Moscow Center Commentary. https://carnegie.ru/commentary/80462. Accessed 18 Oct 2020.

Biden, President Joseph R. 2021. Interim national security strategic guidance. https://www.white house.gov/briefing-room/statements-releases/2021/03/03/interim-national-security-strategicguidance/. Accessed 20 Apr 2021.

Blank, Stephen. 2019. After the INF: Russia's propaganda and real threats. Eurasia Daily Monitor. https://Jamestown.org/program/after-the-inf-russias-propaganda-and-real-threats/. Accessed 7 Mar 2020.

Congressional Budget Office. 2019. Projected costs of U.S. nuclear forces 2019-2028. https://www. cbo.gov/system/files/2019-01/54914-NuclearForces.pdf. Accessed 18 Apr 2021.

Einhorn, Robert J., and Gary Samore. 2002. Ending Russian assistance to Iran's nuclear bomb. Survival 44 (2): 51-70.

Ford, Christopher A. 2020. U.S. priorities for next-generation arms control. Arms Control and International Security Papers 1 (1): 1-14.

Fravel, M. Taylor. 2007. Power shifts and escalation: Explaining China's use of forces in territorial disputes. International Security 32 (3): 44-83.

Gallagher, Nancy. 2019. China on arms control, nonproliferation, and strategic stability. CISSM Working Paper. https://cissm.umd.edu/sites/default/files/2019-08/China\%20on\%20Arms\%20Con trol\%2C\%20Nonproliferation\%2C\%20and\%20Strategic\%20Stability_082619_0.pdf. Accessed 7 June 2021.

Garamone, Jim. 2018. National defense strategy: A good fit for our times, Mattis Says. Department of Defense News. https://www.defense.gov/News/Article/Article/1419671/national-defense-strategy-agood-fit-for-our-times-mattis-says/. Accessed 18 Apr 2019.

Glaser, C.L., and Steve Fetter. 2016. Should the United States reject MAD? Damage limitation and U.S. nuclear strategy toward China. International Security 41 (1): 49-98.

Gorbachev, Mikhail. 2018. A new nuclear arms race has begun. Gulf News. https://gulfnews.com/opinion/ op-eds/a-new-nuclear-arms-race-has-begun-1.2294911. Accessed 18 Apr 2019.

Green, Brendan R., and Austin Long. 2017. The MAD who wasn't there: Soviet reactions to the late cold war nuclear balance. Security Studies 26 (4): 606-641.

Kobza, Robert. 2019. Another tool in the toolbox: Using intermediate-range missiles to counter A2/AD in the Pacific. Georgetown Security Studies Review. https://georgetownsecuritystudiesreview.org/ 2019/12/02/another-tool-in-the-toolbox-using-intermediate-range-missiles-to-counter-chinese-a2ad-in-the-pacific/. Accessed 7 June 2021.

Kristensen, Hans M., and Matt Korda. 2020a. United States nuclear forces 2020. Bulletin of the Atomic Scientist 76 (1): 46-60. https://doi.org/10.1080/00963402.2019.1701286.

Kristensen, Hans M., and Matt Korda. 2020b. Russian nuclear forces 2020. Bulletin of the Atomic Scientists 76 (2): 102-117. https://doi.org/10.1080/00963402.2020.1728985.

Kristensen, Hans M., and Matt Korda. 2021. Status of world nuclear forces. Federation of American Scientists. https://fas.org/issues/nuclear-weapons/status-world-nuclear-forces/. Accessed 7 June 2021.

Mehta, Aaron. 2019. Watch the Pentagon test a previously banned ballistic missile. Defense News. https:// www.defensenews.com/space/2019/12/12/pentagon-tests-previously-banned-ballistic-missile/? from=timeline. Accessed 18 Nov 2020.

Mercado, Vic. 2020. A nuclear sea-launched cruise missile will help deter nuclear aggression. Defense News. https://www.defensenews.com/opinion/commentary/2020/08/05/a-nuclear-sea-launchedcruise-missile-will-help-deter-nuclear-aggression/. Accessed 18 Apr 2021.

Ministry of Foreign Affairs of the PRC. 2020. Director-General FU Cong's interview with Kommersant. https://www.fmprc.gov.cn/mfa_eng/wjbxw/t1824545.shtml. Accessed 20 Feb 2021.

Nuclear Threat Initiative. 2015. The delivery systems threat. http://www.nti.org/learn/delivery-systems/. Accessed 18 Apr 2019. 
Ogilvie, Tanya. 2020. Post-INF arms control in the Asia-Pacific: Political viability and implementation challenges. The International Institute for Strategic Studies. https://www.iiss.org/blogs/researchpaper/2020/06/post-inf-arms-control-asia-pacific. Accessed 7 June 2021.

Pan, Zhengqiang. 2018. A study of China's no-first-use policy on nuclear weapons. Journal for Peace and Nuclear Disarmament 1 (1): 115-136.

President of Russia. 2018. Presidential address to Federal Assembly. http://en.kremlin.ru/events/presi dent/news/56957. Accessed 18 Apr 2019.

Quinn, Leanne. 2019. China's stance on nuclear arms control and New START. Arms Control Association. https://www.armscontrol.org/blog/2019-08-23/chinas-stance-nuclear-arms-control-new-start. Accessed 20 Oct 2020.

Russian Federation Defence Ministry. 2018. Supreme Commander-in-Chief of the Russian Federation attends extended session of the Russian Defence Ministry board session. http://eng.mil.ru/en/news_ page/country/more.htm?id=12208613@egNews. Accessed 20 Dec 2019.

Shambaugh, David. 2005. Power shift: China and Asia's new dynamics. University of California Press.

Sonne, Paul, and John Hudson. 2019. Trump orders staff to prepare arms-control push with Russia and China. The Washington Post. https://www.washingtonpost.com/world/national-security/trumporders-staff-to-prepare-arms-control-push-with-russia-and-china/2019/04/25/c7f05e04-6076-11e99412-daf3d2e67c6d_story.html. Accessed 18 Apr 2020.

Squassoni, Sharon. 2021. How the Biden administration can secure real gains in nuclear arms control. https://thebulletin.org/2021/03/how-the-biden-administration-can-secure-real-gains-in-nucleararms-control/. Accessed 18 Apr 2021.

Stokes, Jacob. 2019. China's missile program and U.S. withdrawal from the Intermediate-Range Nuclear Forces (INF) Treaty. U.S.-China Economic and Security Review Commission Staff Research Report. https://www.uscc.gov/sites/default/files/Research/China\%20and\%20INF_0.pdf. Accessed 6 June 2021.

The Guardian. 2019. Russia is helping China build a missile defence system, Putin Says. http://www.thetr uthseeker.co.uk/?p=195809. Accessed 18 Apr 2019.

U.S. Congressional Research Service. 2019. Russian compliance with the Intermediate Range Nuclear Forces (INF) Treaty: Background and issues for Congress. https://fas.org/sgp/crs/nuke/R43832.pdf. Accessed 18 Feb 2021.

U.S. Department of Defense. 2018. The nuclear posture review. https:/fas.org/wp-content/uploads/ media/2018-Nuclear-Posture-Review-Version-2.pdf. Accessed 18 Apr 2019.

U.S. State Department. 2020. Executive summary of findings on adherence to and compliance with arms control, nonproliferation, and disarmament agreements and commitments. https://www.state.gov/ wp-content/uploads/2020/04/Tab-1.-EXECUTIVE-SUMMARY-OF-2020-CR-FINDINGS-04.14. 2020-003-003.pdf. Accessed 18 Apr 2021.

Wu, Riqiang. 2019. Trilateral arms control initiative: A Chinese perspective. https://thebulletin.org/2019/ 09/trilateral-arms-control-initiative-a-chinese-perspective. Accessed 18 Nov 2020.

Zala, Benjamin. 2019. How the next nuclear arms race will be different from the last one. Bulletin of the Atomic Scientists 75 (1): 36-43. https://doi.org/10.1080/00963402.2019.1555999.

Zhao, Tong. 2019. China in a world with no U.S.-Russia treaty-based arms control. Carnegie-Tsinghua Center for Global Policy. https://carnegietsinghua.org/2019/04/01/china-in-world-with-no-u.s.-russia-treaty-based-arms-control-pub-78894. Accessed 7 June 2021. 